\title{
The role of sodium in the salty taste of permeate
}

\author{
K. M. Frankowski, R. E. Miracle, and M. A. Drake ${ }^{1}$ \\ Department of Food, Bioprocessing and Nutrition Sciences, Southeast Dairy Foods Research Center, North Carolina State University, \\ Raleigh 27695
}

\section{ABSTRACT}

Many food companies are trying to limit the amount of sodium in their products. Permeate, the liquid remaining after whey or milk is ultrafiltered, has been suggested as a salt substitute. The objective of this study was to determine the sensory and compositional properties of permeates and to determine if elements other than sodium contribute to the salty taste of permeate. Eighteen whey $(\mathrm{n}=14)$ and reduced-lactose (n $=4$ ) permeates were obtained in duplicate from commercial facilities. Proximate analyses, specific mineral content, and nonprotein nitrogen were determined. Organic acids and nucleotides were extracted followed by HPLC. Aromatic volatiles were evaluated by gas chromatography-mass spectrometry. Descriptive analysis of permeates and model solutions was conducted using a trained sensory panel. Whey permeates were characterized by cooked/milky and brothy flavors, sweet taste, and low salty taste. Permeates with lactose removed were distinctly salty. The organic acids with the highest concentration in permeates were lactic and citric acids. Volatiles included aldehydes, sulfurcontaining compounds, and diacetyl. Sensory tests with sodium chloride solutions confirmed that the salty taste of reduced-lactose permeates was not solely due to the sodium present. Permeate models were created with $\mathrm{NaCl}, \mathrm{KCl}$, lactic acid, citric acid, hippuric acid, uric acid, orotic acid, and urea; in addition to $\mathrm{NaCl}, \mathrm{KCl}$, lactic acid, and orotic acid were contributors to the salty taste.

Key words: permeate, salty taste, sodium

\section{INTRODUCTION}

Currently, Americans consume too much salt. The average intake of sodium chloride in the United States is $3,000 \mathrm{mg} / \mathrm{d}$, whereas the recommended intake is 1,500 to $2,400 \mathrm{mg} / \mathrm{d}$ (USDA, 2010). Most of this salt comes from processed foods, not from addition of salt

Received February 15, 2014.

Accepted June 2, 2014.

${ }^{1}$ Corresponding author: maryanne_drake@ncsu.edu to food (Anderson et al., 2010). High sodium intake is linked to many adverse health conditions, including hypertension and cardiovascular disease. According to the US Department of Health and Human Services (2006), 65 million Americans suffer from hypertension.

Many studies have shown the correlation between sodium and hypertension; however, people are still hesitant about low-sodium diets (Mattes and Donnelly, 1991; US FDA, 2008; Kim et al., 2012). Fifty percent of consumers want to decrease their sodium intake but do not want to lose the flavor of their foods (NMI, 2008). Kim et al. (2012) recently demonstrated that consumers are aware of the link between certain medical conditions, such as hypertension, and high sodium consumption. Even though consumers are aware of this relationship, salt is considered a "must have" attribute by consumers in food. Consumers also preferred a reduced-sodium version of the food product compared with a sodium-free product.

The food industry is currently trying to reduce the amount of sodium in food products (Berry, 2010). Sodium reduction can be achieved by changes in formulation as well as by use of other salt replacers to help provide the water activity and flavor properties contributed by salt. Studies with salt replacers have been ongoing for many years, and these salt replacers are often other halide salts, such as $\mathrm{KCl}$. These salts usually have another taste besides salt in them. For example, $\mathrm{KCl}$ is perceived as salty, bitter, and metallic (Murphy et al., 1981; Sinopoli and Lawless, 2012), and it is often used in conjunction with $\mathrm{NaCl}$ because $\mathrm{NaCl}$ $\mathrm{KCl}$ blends reduce the bitter taste of the $\mathrm{KCl}$ (Breslin and Beauchamp, 1995). Sodium reduction in food is challenging because of the many roles that sodium plays in foods (e.g., structure, water activity, safety) as well as consumer expectations of salty taste (Kim et al., 2012). Other studies have challenged the categorical assignation of 5 basic tastes and demonstrated that compounds that are primarily "salty," such as sodium chloride, also display other sensory characteristics when evaluated in simple water solutions, much less in more complex foods (Gillette, 1985; Delwiche, 1996).

Monosodium glutamate, which displays both salty taste, due to its sodium component, and umami taste, 
has been used to reduce the amount of sodium added to foods. Other compounds do not contribute salty taste to a product but will enhance salty taste that is already found in the product; these are known as flavor enhancers. The most common salty-taste enhancer is monosodium glutamate (MSG). Organic acids, nucleotides, and NPN compounds are also used to enhance flavor and may be salty-taste enhancers (Schiffman et al., 1981; Salles et al., 2002; Kang et al., 2007). The acid that elicited the highest increase in salty taste was citric acid. Lactic acid was also used successfully to increase salty taste in ramen-style soups (Kang et al., 2007). Nucleotides also have an effect on salty taste. Monosodium glutamate has been shown to enhance salty taste in other studies (Yamaguchi and Takahashi, 1984; Roininen et al., 1996; Okiyama and Beauchamp, 1998). Ball et al. (2002) reported that when $\mathrm{NaCl}$ levels were reduced to $85 \mathrm{~m} M$ and glutamate was added, soups had equal or higher salty taste intensity compared with control $\mathrm{NaCl}$ levels. They also found no difference between adding monosodium glutamate or calcium diglutamate in terms of enhancing salty taste in the soups (Ball et al., 2002).

Permeate, also known as dairy product solids, deproteinized whey, or modified whey, is the liquid that remains after UF of whey or milk; it is a byproduct of the manufacture of whey and milk protein concentrate or isolate. Minerals and lactose removed during membrane fractionation are found in permeate. The approximate dry weight composition of permeate is 65 to $85 \%$ lactose, 8 to $20 \%$ ash or minerals, 3 to $8 \%$ protein, and less than 1.5\% fat (US Dairy Export Council, 2011). Reduced-lactose permeate has had a portion of the lactose removed by crystallization and has approximately 3 times the mineral content of regular permeate (US Dairy Export Council, 2011). Permeate production has increased by about $17 \%$ per year from 2005 to 2009 (Gerdes, 2011). Whey protein ingredients are popular functional ingredients, but permeate is still mostly viewed as a byproduct. Permeate currently has applications in infant formulas and baked goods. Recent research has proposed the use of permeate as a salt replacer in food products (Archwamety, 2012). Permeate contains sodium but it is not known if other components of permeate have properties that enhance salty taste. If other components in permeate contribute to salty taste, permeate could be used in food applications in place of sodium to reduce sodium in foods. The objective of this study was to evaluate the composition of permeates and to determine the sensory properties of permeate and permeate components to determine if components in addition to $\mathrm{Na}$ were responsible for the salty taste.

\section{MATERIALS AND METHODS}

\section{Permeates}

A total of 18 permeates ( 7 powders and 11 liquids) from 12 commercial suppliers were obtained in duplicate. These included whey permeates $(\mathrm{n}=14)$ and reduced-lactose whey permeates $(n=4)$. All permeates were from sweet whey from rennet-set cheese manufacture. Upon receipt, liquid samples were stored at $-20^{\circ} \mathrm{C}$ and powders were stored at $21^{\circ} \mathrm{C}$ until analysis $(<2$ wk).

\section{Proximate Analysis}

Total solids were determined using a vacuum oven (AOAC International, 2000; method 927.5), and fat was determined by Mojonnier method (AOAC International, 2000; method 989.05). Sodium, potassium, calcium, magnesium, and ash contents were determined by inductively coupled plasma spectrophotometry (ICP) by the North Carolina State University Analytical Services Laboratory (Raleigh). Chloride was measured potentiometrically using a silver ion electrode on a salt analyzer (SAT-500, Tokyo, Japan). Lactose was determined enzymatically using a lactose assay kit (Abcam, Cambridge, MA). Protein and NPN were analyzed by Kjeldahl (AOAC International, 2000; methods 991.20, 33.2.11; and 991.21, 33.2.12). A conversion factor of $\mathrm{N}$ $\times 6.38$ was used to determine total protein and NPN values. Duplicate measurements were taken on each permeate for all analyses.

\section{Organic Acids}

Organic acids were extracted using a modified method of Lues et al. (1998). All permeates were analyzed at $20 \%$ solids (low-solids samples were measured as is and the volume was adjusted to make up for difference in solids). Sulfuric acid (20 mL, $0.013 \mathrm{~N}$; Mallinckrodt Chemicals, Hazelwood, MO) was added to a $50-\mathrm{mL}$ centrifuge tube (Nalgene, Rochester, NY). Sample (10 $\mathrm{mL}$ ) was then added to this volume and vortexed and centrifuged at 7,000 $\times g$ for 5 min at $4^{\circ} \mathrm{C}$ (model RC5B, Thermo Scientific, Waltham, MA). The supernatant was then removed and filtered using a $0.45-\mu \mathrm{m}$ nylon syringe filter (VWR International, West Chester, PA).

Organic acids were then measured by HPLC (1525 Binary Pump, Waters, Milford, MA). Sample extract $(20 \mu \mathrm{L})$ was injected onto the HPLC cation column (Aminex HPX-87H, $300 \times 7.8 \mathrm{~mm}$, Bio-Rad Laboratories, Hercules, CA). An isocratic mobile phase of $0.013 N$ sulfuric acid was used at $0.8 \mathrm{~mL} / \mathrm{min}$. Sample was sent through a photodiode array detector (Waters 
2998). A standard curve was created for each of the organic acids. The maxima used for calculation was 254 $\mathrm{nm}$. Orotic and citric acids coeluted at this wavelength, so $285 \mathrm{~nm}$ was used for orotic acid; at this wavelength, citric acid was not detected. Organic acid standards were obtained from Thermo Fisher Scientific Inc. (Pittsburgh, PA).

\section{Nucleotides}

Nucleotides were extracted and measured by HPLC using modified methods described by Oliveira et al. (1999). The nucleotides measured were adenosine monophosphate (AMP), guanosine monophosphate (GMP), inosine monophosphate (IMP), cytidine monophosphate (CMP), and uridine monophosphate (UMP); these nucleotides are those that are most commonly found in dairy products (Oliveira et al., 1999; Ferreira et al., 2001). Each sample was extracted in triplicate and injected onto the HPLC in duplicate. Sample (3 mL, 10\% solids, low-level solids were extracted as is) was measured into a $50-\mathrm{mL}$ centrifuge tube (Nalgene). To this, $2 \mathrm{~mL}$ of $1.0 \mathrm{M}$ formic acid solution (VWR International) was added into the same centrifuge tube. The sample was then vortexed. After vortexing, the samples were centrifuged at $5,000 \times g$ for 10 min at $4^{\circ} \mathrm{C}$ (model RC5B, Thermo Scientific). The top layer $(3 \mathrm{~mL})$ was measured into a new centrifuge tube and $200 \mu \mathrm{L}$ of $1.2 \mathrm{M}$ potassium carbonate (Sigma Aldrich, St Louis, MO) was added. This solution was then vortexed and centrifuged at 5,000 $\times g$ for $10 \mathrm{~min}$ at $4^{\circ} \mathrm{C}$. The supernatant was then filtered through a $0.2-\mu \mathrm{m}$ cellulose acetate membrane syringe filter (VWR International).

After filtering, the sample was injected onto the HPLC (Waters). The injector temperature was set to $4^{\circ} \mathrm{C}$. Twenty microliters of each sample was injected (Waters 2707 Autosampler) onto the column (Spherisorb C18-S10 ODS2: $10 \mu \mathrm{m}, 250 \times 4.6 \mathrm{~mm}$ ). A 2-solvent isocratic mobile phase was used with a gradient flow rate: solvent A consisted of $5 \mathrm{~m} M$ tetrabutylammonium hydrogen sulfate (TBAHS; Thermo Fisher Scientific Inc.) and $20 \mathrm{mM}$ potassium dihydrogen sulfate (Alfa Aesar, Ward Hill, MA) and solvent B consisted of $5 \mathrm{~m} M$ TBAHS and $100 \mathrm{~m} M$ dipotassium hydrogen phosphate (Alfa Aesar). The gradient flow rate was as follows: $0-20 \mathrm{~min}$ at $0.7 \mathrm{~mL} / \mathrm{min}$; at $21-25 \mathrm{~min}$, the flow rate was increased to $1.5 \mathrm{~mL} / \mathrm{min}$; at $26 \mathrm{~min}$, the flow was decreased to $0.7 \mathrm{~mL} / \mathrm{min}$ and then gradually increased to $1.5 \mathrm{~mL} / \mathrm{min}$ until $37 \mathrm{~min}$ and maintained until $44 \mathrm{~min}$. Sample was sent through a photodiode array detector (Waters 2998). A standard curve was created by diluting each nucleotide (Sigma Aldrich) in water. The maxima used for calculation was $260 \mathrm{~nm}$.

\section{Volatile Compound Analysis}

Volatile compounds of permeates were determined using solid-phase microextraction (SPME) GC-MS. Compounds were extracted and identified using a modified method described by Campbell et al. (2013). Five grams of permeate ( $10 \%$ solids wt/vol), $10 \%$ (wt/vol) $\mathrm{NaCl}$, and an internal standard (2-methyl-3-heptanone in methanol at $81 \mathrm{mg} / \mathrm{kg}$; Sigma Aldrich) were added to $20-\mathrm{mL}$ amber autosampler vials with steel screw tops with silicone septa faced in Teflon (Microliter Analytical, Suwanee, GA).

Samples were injected using a CombiPal autosampler (CTC Analytics, Zwingen, Switzerland) attached to an Agilent 7820A GC with 5975 MS (Agilent Technologies Inc., Santa Clara, CA). Before exposure, samples were maintained at $5^{\circ} \mathrm{C}$, and then the SPME fibers (1-cm divinylbenzene/carboxen/polydimethylsiloxane fiber; DVB/CAR/PDMS, Supelco, Bellefonte, PA) were exposed for $30 \mathrm{~min}$. The initial temperature at exposure was $40^{\circ} \mathrm{C}$ and was increased to $250^{\circ} \mathrm{C}$ at a rate of $10^{\circ} \mathrm{C} /$ min. A Zb-5MS column $(30 \mathrm{~m}$ long $\times 0.25 \mathrm{~mm}$ i.d. $\times$ 0.25- $\mu \mathrm{m}$ film thickness; Phenomenex, Torrance, CA) was used at a flow rate of $1 \mathrm{~mL} / \mathrm{min}$. The purge time was $1 \mathrm{~min}$, the MS transfer line was at $250^{\circ} \mathrm{C}$, with the quad at $150^{\circ} \mathrm{C}$ and the source at $250^{\circ} \mathrm{C}$. Relative abundance was determined for each compound using the calculated recovery of the internal standard. Compound identities were confirmed by comparisons of retention indices and mass spectra against those of authentic standards.

\section{Descriptive Analysis}

Descriptive sensory analysis was conducted to characterize both aromatics and tastes of each permeate and tastes of salts and salt blend solutions $\left(\mathrm{KCl}, \mathrm{MgCl}_{2}\right.$, $\mathrm{CaCl}_{2}$; USP grade, Avantor Performance Materials, Phillipsburg, NJ), and combinations of 90:10 Na:K, 75:25 Na:K, 50:50 Na:K, 25:75 Na:K, 50:40:10 Na:K:Ca, and 50:40:10 Na:K:Mg). Permeates (10\% solids wt/vol or tested as is for low-solids liquids) were evaluated by a trained sensory panel $(\mathrm{n}=8 ; 7$ females, 1 male, aged 24-49 yr) using an established dried dairy ingredient flavor lexicon (Drake et al., 2003; Wright et al., 2009) and a universal intensity scale consistent with the Spectrum method. All testing was done in accordance with the guidelines of the North Carolina State University Institutional Review Board for Human Subjects. Liquids (tested as-is for low solids or diluted to $10 \% \mathrm{wt} /$ vol solids) and rehydrated powder permeates (10\% wt/ vol) or salt solutions were dispensed into $60-\mathrm{mL}$ plastic cups (Solo Cup Co., Champaign, IL) with 3-digit codes for tasting. Salt and salt blend solutions were prepared 
and evaluated at threshold, $5 \times$ threshold, and $10 \times$ threshold to document the taste(s) perceived and the intensities. Each permeate or salt solution was evaluated in duplicate by each panelist. Compusense Five, version 4.8 (Compusense, Guelph, ON, Canada) was used for data collection.

\section{Threshold Determination}

Sensory testing was conducted in compliance with the North Carolina State University Institutional Review Board for Human Subjects. Best estimate detection taste thresholds of salts and salt blends $\left(\mathrm{NaCl}, \mathrm{KCl}, \mathrm{MgCl}_{2}, \mathrm{CaCl}_{2}\right.$ ) and combinations of 90:10 $\mathrm{NaCl}: \mathrm{KCl}, \quad 75: 25 \quad \mathrm{NaCl}: \mathrm{KCl}, \quad 50: 50 \quad \mathrm{NaCl}: \mathrm{KCl}, \quad 25: 75$ $\mathrm{NaCl}: \mathrm{KCl}, \quad 50: 40: 10$ NaCl:KCl:CaCl${ }_{2}$, and 50:40:10 $\mathrm{NaCl}: \mathrm{KCl}: \mathrm{MgCl}_{2}$ were determined. A modified method of ASTM procedure E679-91 (ASTM, 1992), an ascending forced choice method, was used. A separate threshold test was conducted for each salt and salt blend. Solutions were prepared in distilled water and were at $21^{\circ} \mathrm{C}$ in $60-\mathrm{mL}$ coded and lidded plastic cups. The samples were presented at 7 different ascending concentrations with a step factor of 3 . At each concentration, the panelist received 3 samples: 2 water blanks and 1 with one of the salts mentioned previously.

Subjects ( $\mathrm{n}=40$, ages $21-50 \mathrm{yr}$ ) were instructed before testing. Subjects were instructed to taste every sample in each set and select the 3 -digit coded cup they thought was different from the other 2, as well as state whether or not they were sure. A 3-min enforced rest occurred between each set and subjects were instructed to rinse with spring water during this time. Noseclips (Adinstruments, Colorado Springs, CO) were worn by each panelist throughout testing to ensure that differences were due to tastes and not aromatics. The individual best estimate threshold (BET) was determined by taking the geometric mean of the last incorrect series and the first correct series. If the subject was unsure, a correction factor was applied (Lawless et al., 2000; Drake et al., 2007). The group BET was calculated by taking the geometric mean of the calculated individual BET.

\section{Taste Response Curves}

Sodium chloride and lactose- $\mathrm{NaCl}$ intensity curves were constructed based from concentrations found in permeate. Sodium chloride at concentrations of 0.03 , $0.08,0.13,00.20,0.35$, and $0.50 M$, dissolved into deionized water, was evaluated. These solutions were also evaluated with the addition of 5 and $10 \%$ lactose (Thermo Fisher Scientific Inc.) to mimic the composition of permeates. The samples were dispensed into 60-mL 3-digit-coded plastic cups and lidded. Sensory analysis of tastes was conducted using the trained panel described previously.

\section{Model Permeates}

Permeate models were constructed with $\mathrm{KCl}$, lactic acid, citric acid, hippuric acid, orotic acid, and urea added to $\mathrm{NaCl}$ :lactose solutions described previously. These were the potential contributors of salty taste. Potassium chloride was evaluated at 2 concentrations: 0.5 and $0.1 M$, the mean concentrations of the whey and reduced-lactose permeates, respectively. These were added to each concentration of $\mathrm{NaCl}$ and $\mathrm{NaCl}$ :lactose previously evaluated. The solutions were then dispensed into coded plastic 60-mL soufflé cups (Solo Cup Co.) and lidded. Sensory analysis of tastes was conducted using the trained panel described previously. This process was repeated with $0.01 M$ lactic acid, $1 \mathrm{~m} M$ citric acid, $0.69 \mathrm{~m} M$ hippuric acid, $3.84 \mathrm{~m} M$ orotic acid, 1.78 $\mathrm{m} M$ uric acid, and $0.52 M$ urea (concentration averages found in permeate). After individual models were completed, a model was generated in the same process with all the salts and acids in one model. Models were prepared and evaluated in duplicate.

\section{Proof of Concept}

Two whey permeates (1 powder and 1 liquid), from different suppliers, with the lowest salty taste intensities were selected to demonstrate salty-taste enhancement with $\mathrm{KCl}$ and lactic acid. The dried whey permeate was rehydrated to $10 \%$ (wt/vol) solids. The liquid sample was $8 \%$ solids (wt/vol) and was used as is. Then, $\mathrm{KCl}$ was added at $0.1 M$ and lactic acid was added at 0.01 $M$ (the concentrations found in models to enhance salty taste). This was repeated with $0.1 \mathrm{M} \mathrm{KCl}, 0.01 M$ lactic, and $3.84 \mathrm{~m} M$ orotic acid. Solutions were dispensed into coded plastic soufflé cups and lidded. Samples were evaluated in duplicate as previously described.

\section{Statistical Analysis}

Data were analyzed using XLSTAT (version 2010; Addinsoft, New York, NY). One-way ANOVA and principal component analysis were used to evaluate differences among different permeate types and model solutions. Fisher's least significant difference was used as a post hoc test. Correlation analysis was applied to determine if individual permeate components were related to salty taste intensity.

\section{RESULTS}

\section{Proximate Analysis}

Permeate composition was variable (Tables 1 and 2) but consistent with reported values (US Dairy Ex- 
Table 1. Proximate analysis averages of permeates

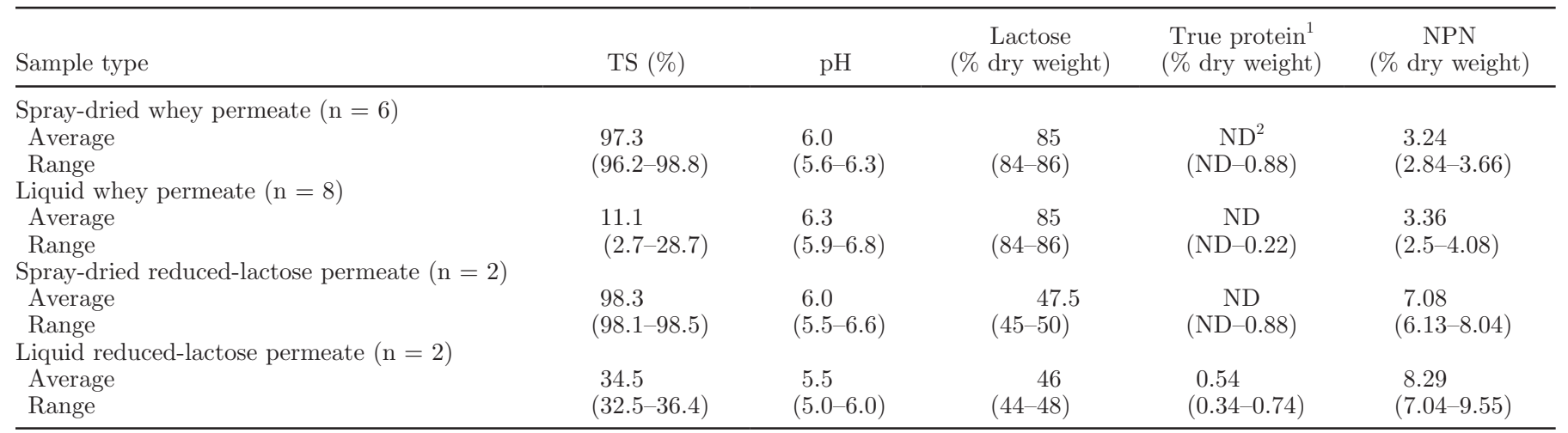

${ }^{1}$ True protein is the actual amount of protein in sample (total protein - NPN).

${ }^{2} \mathrm{ND}=$ not detected.

port Council, 2011). Total solids had the widest range because both liquids and powders were provided. All permeates were less than $0.5 \%$ fat. Potassium was the most abundant mineral in permeates followed by sodium. Mineral concentrations were higher in reducedlactose permeates than in whey permeates $(P<0.05)$. Reduced-lactose permeate is the byproduct from lactose crystallization. The first step in lactose crystallization is to concentrate permeate in an evaporator. Lactose, minerals, and other compositional elements are also concentrated. The $\mathrm{pH}$ of fresh Cheddar whey is 6.4 to 6.7 (Girsh, 2001), and the pH of whey will decrease if whey is not heat treated to inactivate lactic acid bacteria (Girsh, 2001). According to the US Dairy Export Council (2011), the pH of permeate should be between 5.7 and 6.5. The permeates in this study were within this range. Protein values in permeates would be expected to be low. Permeate is the byproduct of UF of whey or milk to produce a higher protein concentration, and proteins are not permeable to the UF membrane. Nonprotein nitrogen is nitrogen that is not associated with protein. The NPN values in the current study were consistent with those published for whey (Moatsou et al., 2003). The majority of the NPN found in permeate is most likely urea because it is a major part of the cow's diet (Huber, 1975) and is also present in milk (Shahani and Sommer, 1951).

\section{Organic Acids and Nucleotides}

The organic acids with the highest concentrations in all permeates were lactic and citric acids (Table 3 ). Whey permeates were highly variable in the concentration of these acids (180 to $2,000 \mathrm{mg} / \mathrm{kg}$ for citric acid, 140 to $1,900 \mathrm{mg} / \mathrm{kg}$ for lactic acid). Whey permeate composition varies widely between suppliers (Gerdes, 2011) and varies because of several factors, from cheese type to storage and processing of the permeate. Citric acid is found naturally in milk as an end product of bovine metabolism (Marsili et al., 1981). The reducedlactose permeates had the highest concentrations of citric and lactic acids (mean $=4,403$ and $6,000 \mathrm{mg} / \mathrm{kg}$, respectively) compared with those for the 14 whey permeates $(1,110$ and $897 \mathrm{mg} / \mathrm{kg}$, respectively; $P<0.05)$. The concentration of citric acid in reduced-lactose permeates was at least twice that in whey permeate.

Citric acid concentration in the whey permeates was similar to that in milk and whey. Mullin and Emmons (1997) report the concentration of citric acid in milk to be $1,580 \mathrm{mg} / \mathrm{kg}$ and in whey products to be $>1,000 \mathrm{mg} /$ $\mathrm{kg}(1,040$ to $1,580 \mathrm{mg} / \mathrm{kg})$. Lactic acid concentrations are lower in whey and milk than in permeate. Lactic acid is not detected in fluid milks and the concentration in whey is $<500 \mathrm{mg} / \mathrm{kg}$ (Mullin and Emmons, 1997). The concentration of lactic acid is likely higher

Table 2. Average mineral concentration (\% dry weight) of permeates

\begin{tabular}{lcccccc}
\hline Sample type & $\mathrm{K}$ & $\mathrm{Ca}$ & $\mathrm{Mg}$ & $\mathrm{Na}$ & $\mathrm{Cl}$ & $\mathrm{Ash}$ \\
\hline Whey permeate & & & & & \\
$\quad$ Average & 2.13 & 0.54 & 0.12 & 0.98 & 0.21 & 8.26 \\
$\quad$ Range & $(1.54-3.48)$ & $(0.36-0.86)$ & $(0.11-0.14)$ & $(0.70-1.33)$ & $(0.07-0.67)$ & $(5.28-11.8)$ \\
$\quad$ Reduced-lactose permeate & & & & & & \\
$\quad$ Average & 6.04 & 1.51 & 0.25 & 2.39 & 1.03 & 21.8 \\
$\quad$ Range & $(4.24-7.38)$ & $(0.43-3.55)$ & $(0.21-0.27)$ & $(1.68-3.50)$ & $(0.79-1.79)$ & $(20.7-22.9)$ \\
\hline
\end{tabular}


Table 3. Organic acid concentrations $(\mathrm{mg} / \mathrm{kg})$ in permeates

\begin{tabular}{|c|c|c|c|c|c|}
\hline Sample $^{1}$ & Citric & Orotic & Lactic & Uric & Hippuric \\
\hline \multicolumn{6}{|c|}{ Whey permeate } \\
\hline S1 & $1,770^{\mathrm{d}}$ & $543.0^{\mathrm{ef}}$ & $1,896^{\mathrm{de}}$ & $227.0^{\mathrm{e}}$ & $12.00^{\mathrm{efg}}$ \\
\hline $\mathrm{S} 2$ & $1,943^{\mathrm{d}}$ & $584.0^{\mathrm{de}}$ & $1,096^{\text {ef }}$ & $321.0^{\mathrm{e}}$ & $12.00^{\mathrm{efg}}$ \\
\hline S3 & $1,837^{\mathrm{d}}$ & $781.0^{\mathrm{cd}}$ & $1,422^{\mathrm{ef}}$ & $644.0^{\mathrm{de}}$ & $124.0^{\mathrm{a}}$ \\
\hline $\mathrm{S} 4$ & $1,795^{\mathrm{d}}$ & $685.0^{\text {de }}$ & $1,517^{\mathrm{ef}}$ & $377.0^{\mathrm{de}}$ & $14.00^{\text {defg }}$ \\
\hline S5a & $1,939^{\mathrm{d}}$ & $643.0^{\text {de }}$ & $966.0^{\mathrm{ef}}$ & $267.0^{\mathrm{e}}$ & $14.00^{\mathrm{def}}$ \\
\hline $\mathrm{S} 5 \mathrm{~b}$ & $2,049^{\mathrm{d}}$ & $639.0^{\mathrm{de}}$ & $1,614^{\mathrm{ef}}$ & $299.0^{\mathrm{e}}$ & $14.00^{\mathrm{def}}$ \\
\hline S6 & $2,203^{\text {cd }}$ & $755.0^{\text {cde }}$ & $118.0^{\mathrm{f}}$ & $1,960^{\mathrm{c}}$ & $29.00^{c}$ \\
\hline S7a & $1,176^{\text {de }}$ & $283.0^{\mathrm{fg}}$ & $1,149^{\mathrm{ef}}$ & $992.0^{\mathrm{d}}$ & $17.00^{\text {cdef }}$ \\
\hline $\mathrm{S} 7 \mathrm{~b}$ & $1,651^{\mathrm{de}}$ & $247.0^{\mathrm{g}}$ & $902.0^{\mathrm{ef}}$ & $1,043^{\mathrm{d}}$ & $27.00^{\mathrm{c}}$ \\
\hline S8 & $152.0^{\mathrm{e}}$ & $69.00^{\mathrm{g}}$ & $117.0^{\mathrm{f}}$ & $178.0^{\mathrm{e}}$ & $\mathrm{ND}^{2}$ \\
\hline S9 & $42.00^{\mathrm{e}}$ & $58.00^{\mathrm{g}}$ & $203.0^{\text {ef }}$ & $27.00^{\mathrm{e}}$ & ND \\
\hline S10 & $123.0^{\mathrm{e}}$ & $63.00^{\mathrm{g}}$ & $140.0^{\mathrm{f}}$ & $28.00^{\mathrm{e}}$ & ND \\
\hline S11 & $671.0^{\mathrm{de}}$ & $142.0^{\mathrm{g}}$ & $522.0^{\text {ef }}$ & $331.0^{\mathrm{de}}$ & ND \\
\hline $\mathrm{S} 12$ & $180.0^{\mathrm{e}}$ & $63.00^{\mathrm{g}}$ & $906.0^{\mathrm{ef}}$ & $200.0^{\mathrm{e}}$ & ND \\
\hline \multicolumn{6}{|c|}{ Reduced-lactose permeate } \\
\hline $\mathrm{S} 1$ & $2,528^{\mathrm{bcd}}$ & $1,292^{\mathrm{b}}$ & $6,586^{\mathrm{b}}$ & $1,034^{\mathrm{d}}$ & $29.00^{\mathrm{c}}$ \\
\hline $\mathrm{S} 2$ & $3,434^{\mathrm{bc}}$ & $622.0^{\mathrm{de}}$ & $2,918^{\text {cd }}$ & $492^{\text {de }}$ & $21.00^{\mathrm{cd}}$ \\
\hline S3 & $7,478^{\mathrm{a}}$ & $1,000^{\mathrm{bc}}$ & $4,131^{\mathrm{cd}}$ & $4,858^{\mathrm{d}}$ & $46.00^{\mathrm{b}}$ \\
\hline S4 & $4,173^{\mathrm{b}}$ & $1,618^{\mathrm{a}}$ & $1.040 \times 10^{4 \mathrm{a}}$ & $7,762^{\mathrm{a}}$ & $124.0^{\mathrm{a}}$ \\
\hline
\end{tabular}

${ }^{\mathrm{a}-\mathrm{g}}$ Means with different superscript letters within a column for each permeate type indicate significant differences $(P<0.05)$.

${ }^{1} \mathrm{~S}=$ supplier; $\mathrm{a}$ and $\mathrm{b}$ denote different products by same supplier.

${ }^{2} \mathrm{ND}=$ not detected.

in permeate than in whey products because lactic acid is a small, water-soluble molecule (3-carbon chain, molecular weight of $90.08 \mathrm{~g} / \mathrm{mol}$ ) that is able to cross membranes during UF and into the permeate.

Orotic, uric, and hippuric acids were also detected in whey (mean $=400,490$, and $20 \mathrm{mg} / \mathrm{kg}$, respectively) and reduced-lactose permeate (mean $=1,130,3,500$, and $55 \mathrm{mg} / \mathrm{kg}$, respectively). Orotic acid is a precursor of nucleic acid bases and an intermediate in pyrimidine synthesis (Stryer et al., 1989); it is found in milk. The amount of orotic acid in milk varies with the cow diet but ranges from 19 to $664 \mathrm{mg} / \mathrm{kg}$ (Robinson, 1980; Anastasi et al., 2000). This range is similar to that found in whey permeate in the current study. Uric acid is a break-down product of purine nucleotides (Giesecke et al., 1994). Giesecke et al. (1994) reported the concentration of uric acid in cow milk to be $56.2 \mathrm{mg} / \mathrm{kg}$ but it also varied with diet. The concentration of uric acid in permeate was higher than that in milk in the current study. Uric acid concentration varies with the cow's diet; also, permeate concentration also varies greatly, which could account for different concentrations in permeate than in milk. Hippuric acid concentrations in the current study were similar to those previously reported in milk (Marsili et al., 1981).

Neither GMP nor UMP was detected in any of the permeates, and AMP, IMP, and CMP were not detected or were below detection limits in whey permeates. Reduced-lactose permeate had very low concentrations of CMP $(9.3 \pm 3.6 \mu \mathrm{g} / \mathrm{kg})$. Guanosine monophosphate,
UMP, IMP, and AMP were not detected in cow's milk, although CMP was found in cow milk at $0.98 \mathrm{mg} / 100$ $\mathrm{mL}$ by Ferreira (2003). This concentration was lower than the amount in reduced-lactose permeates in the current study. The concentration in reduced-lactose permeates was likely higher than that of milk because reduced-lactose permeate is concentrated during manufacture.

\section{Descriptive Analysis}

Consistent with volatile compound and organic acid differences, distinct flavor differences were documented between whey permeates and reduced-lactose permeates (Figure 1). Whey permeates were characterized by sweet aromatics (cooked/milky, buttery, and graham cracker flavors) and sweet and salty tastes. These flavors have been previously documented in fluid whey, dried whey, and milk powders (Carunchia Whetstine et al., 2003, 2005; Drake et al., 2003). Whey permeates had low salty taste $($ mean $=2.1$ salty taste intensity). The reduced-lactose permeates were distinctly salty (mean $=9.9$ salty taste intensity) with savory aromatics: potato, beefy, and vitamin flavors, and sour and umami tastes. Salty taste was higher in whey permeates than salty taste intensities reported in fluid whey or milk (permeate: $1.0-3.0$ vs. fluid milk or fluid whey: 0.5-1.0; Carunchia Whetstine et al., 2003). Potato/brothy flavor has previously been reported in fluid whey and other dried whey ingredients and has been attributed 


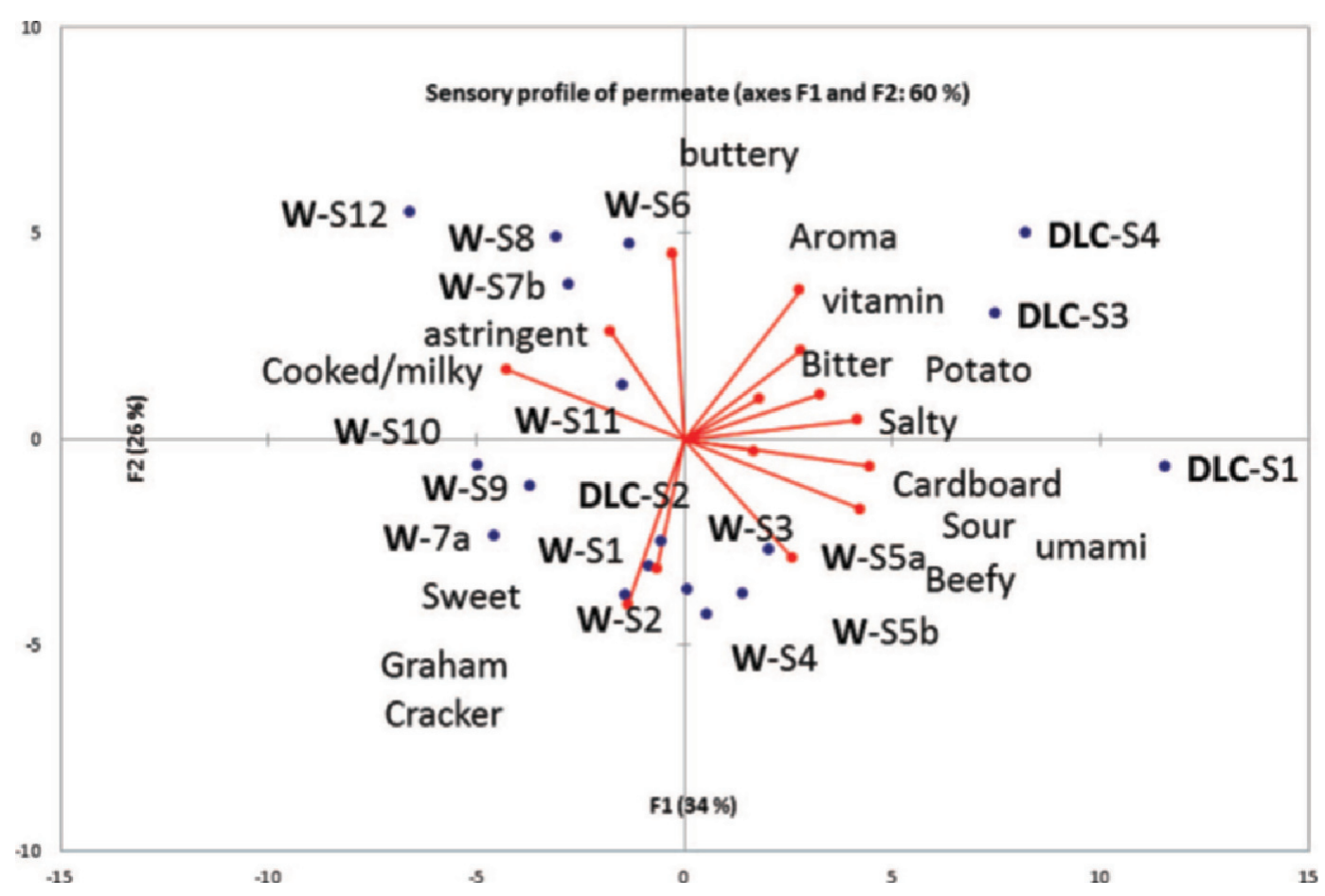

Figure 1. Principal component biplot of sensory profiles of permeates. $\mathrm{W}=$ whey permeates, $\mathrm{DLC}=$ reduced-lactose permeate, $\mathrm{S}=$ supplier, $\mathrm{a}$ and $\mathrm{b}$ represent different products from the same supplier. Color version available in the online PDF.

to methional (Karagul-Yuceer et al., 2002; Mahajan et al., 2004; Carunchia Whetstine et al., 2005). Beefy/ brothy flavor has been documented in Cheddar cheese as well as sour cream and Greek yogurt and has been sourced to 2-methyl-3-furanthiol (Cadwallader et al., 2006; Desai et al., 2013; Shepard et al., 2013).

Flavor differences were also documented between liquid and spray-dried permeates. Liquid permeates had higher intensities of cooked/milk and buttery flavors and sweet taste, whereas spray-dried powders had higher intensities of graham cracker flavor. This suggests that flavor profiles are altered during the spray-drying process. Whitson et al. (2011) reported that spraydried whey concentrate and isolate were more intense in flavor than liquid whey protein retentate and also suggested that this difference was due to spray drying. Cardboard flavor is increased in spray-dried product compared with liquid retentate. Maillard browning reactions also occur during spray draying and may contribute to flavors (Ferretti and Flanagan, 1971, 1972; Labuza and Saltmarch, 1981; O'Brien and Morrissey, 1989).

\section{Volatile Compounds}

Similar volatiles were found in permeates that have been reported in fluid whey and other dairy dried whey products such as whey protein concentrate and sweet whey powders (Karagul-Yuceer et al., 2002; Carunchia Whetstine et al., 2003, 2005; Mahajan et al., 2004; Figure 2). The concentration of volatiles in permeates in the current study was lower than values reported in fluid and dried whey ingredients. These volatiles included aldehydes, sulfur-containing compounds, and diacetyl (Carunchia Whetstine et al., 2003; Mahajan et al., 2004). Sulfur-containing compounds such as dimethyl disulfide and methional are Strecker degradation products of methionine (Ballance, 1961; Tressel et al., 1989) and contribute cabbage and potato aromas (Carunchia Whetstine et al., 2005). Aldehydes were found in all permeate types and included pentanal, hexanal, heptanal, and nonanal. Aldehydes are the result of lipid oxidation (Frankel, 1983). Although present in all samples in the current study, the concentration of aldehydes was highest in the reduced-lactose permeates. Aldehydes in many dairy products increase with heat and storage (Shiratsuchi et al., 1994; Contarini et al., 1997; Vazquez-Landaverde et al., 2005; Whitson et al., 2011). Ultrapasteurized milk has a higher concentration of aldehydes present than either raw milk or pasteurized milk (Contarini and Povolo, 2002; Vazquez-Landaverde et al., 2005). Aldehydes in liquid whey protein concentrate and whey protein isolate retentates are reported to increase with storage (Whitson 


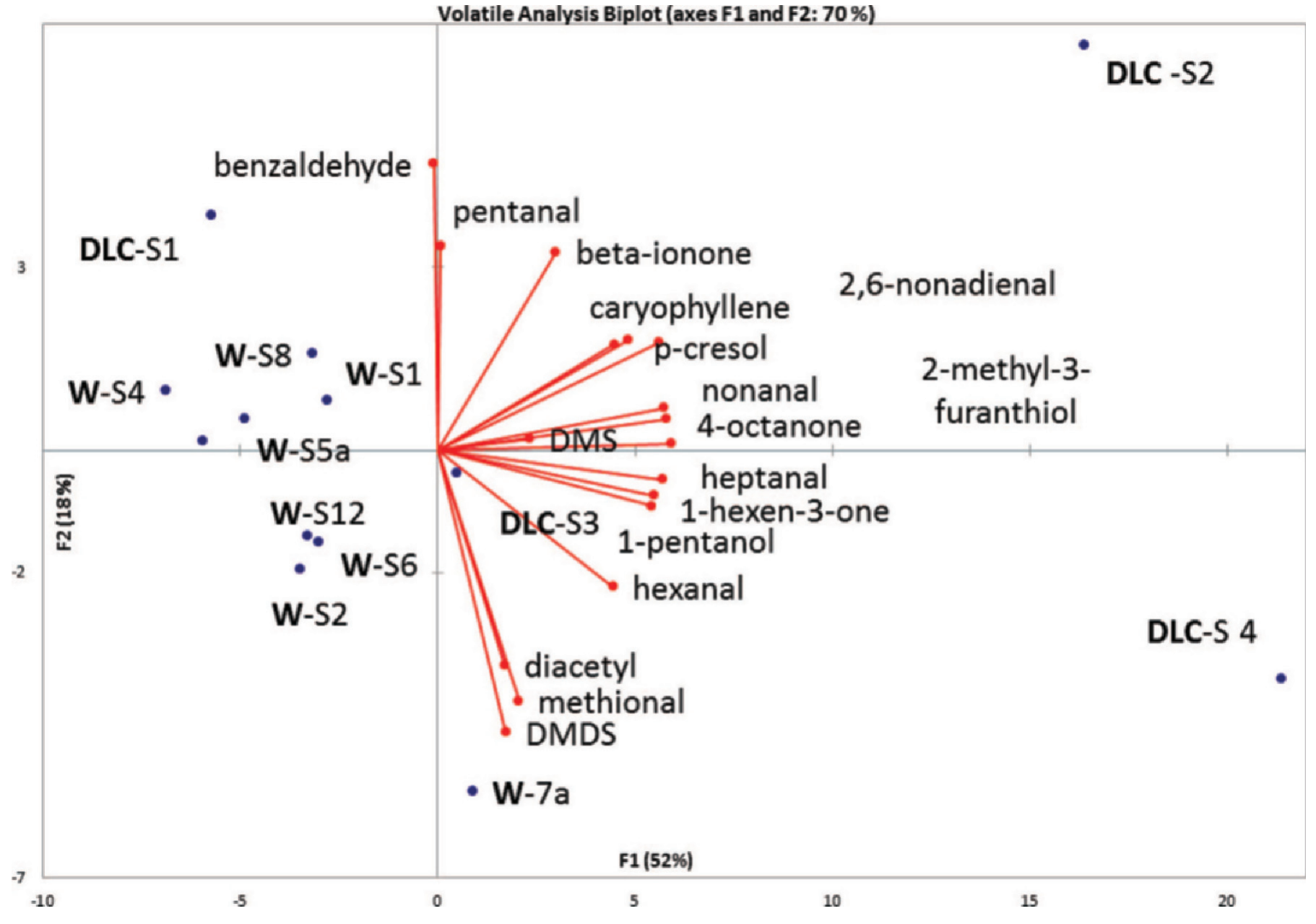

Figure 2. Principal component biplot of volatiles in permeates and reduced-lactose permeates $(\mu \mathrm{g} / \mathrm{kg})$. W $=$ whey permeates, DLC $=$ reduced-lactose permeate, $\mathrm{S}=$ supplier, a and b represent different products from the same supplier. Color version available in the online PDF.

et al., 2011). Reduced-lactose permeate is concentrated through evaporation and is exposed to a high heat load and additional storage and process time, which likely increased the concentration of aldehydes that are present.

Pentanal, heptanal, nonanal, and sulfur compounds are sources of cardboard flavor in whey ingredients (Whitson et al., 2010). Two of the reduced-lactose permeates had cardboard flavor. These 2 permeates also had higher amounts of these aldehydes. Reduced-lactose permeates had higher concentration of volatiles present and also had different volatiles than whey permeates (Figure 2). Reduced-lactose permeates were characterized by 2-methyl-3-furanthiol, heptanal, nonanal, hexanal, and $p$-cresol, which are indicative of longer storage and process time and heat treatment. These results coincide with the sensory profiles of reducedlactose permeates, which were more savory and less sweet than the whey permeates.
Diacetyl was present in all permeates, and whey permeate had the highest concentration of diacetyl. Diacetyl is produced by bacteria during cheese manufacture and is known to impart buttery flavor (Bendall, 2001; Kieronczyk et al., 2003; Mahajan et al., 2004). Because diacetyl is a byproduct of fermentation, we expected that this volatile would be higher in whey permeates than in milk, although diacetyl is also found in raw milk at low concentrations (Karagul-Yuceer et al., 2002; Carunchia Whetstine et al., 2003). Whey permeates were characterized more by diacetyl than were reduced-lactose permeates. Reduced-lactose permeate goes through a period of heat treatment for evaporation and crystallization. Islam and Langrish (2010) found that higher spray-drying and crystallization temperatures increased lactose yields. Diacetyl is decreased by heat; the boiling point of diacetyl is about $88^{\circ} \mathrm{C}$ (Burdock, 2010). $\mathrm{pH}$ is also a factor in reducedlactose permeates because it affects the crystallization 
of lactose (Guu and Zall, 1991). Diacetyl is maximally produced at a $\mathrm{pH}$ of 5.5 (Cachon and Divies, 1993, 1994). The $\mathrm{pH}$ range for reduced-lactose permeates in the current study was below this ideal $\mathrm{pH}$ and, combined with the heat treatment effects, could explain the decreased concentration of diacetyl in reduced-lactose permeate. Liquid permeates had a higher concentration of diacetyl than dried permeates, which may be due to volatilization of diacetyl during the spray-drying process.

\section{Sensory Thresholds and Descriptive Analysis of Tastes of Salts and Blends}

Threshold values in this study were as follows: $\mathrm{KCl}$ $>\mathrm{CaCl}_{2}>\mathrm{MgCl}_{2}>\mathrm{NaCl}$ (results not shown). These thresholds were consistent with values reported in other studies (van Gemert, 2003). Thresholds for NaCl-KCl blends and other salt combinations have not been previously published. Blends had threshold values between the 2 compounds alone. The 90:10 NaCl:KCl blend was most similar in threshold value to pure $\mathrm{NaCl}(115 \mathrm{mg} /$ $\mathrm{kg}$ for blend vs. $127 \mathrm{mg} / \mathrm{kg}$ for pure $\mathrm{NaCl} ; P>0.05$ ). Other $\mathrm{NaCl}: \mathrm{KCl}$ blends had similar threshold concentrations $(221-247 \mathrm{mg} / \mathrm{kg} ; P>0.05)$ that were higher than $\mathrm{NaCl}$ or $90: 10 \mathrm{NaCl}: \mathrm{KCl}(P<0.05)$.

Threshold tests determined detection thresholds (when a difference was perceived). A trained panel was used to document the taste profiles of salts and salt blends. Sodium chloride, $\mathrm{KCl}, \mathrm{MgCl}_{2}$, and $\mathrm{CaCl}_{2}$ all displayed salty taste at threshold levels (results not shown). Potassium chloride was the only salt solution that exhibited bitter taste at threshold concentration; $\mathrm{KCl}$ has been studied extensively and bitter taste is commonly reported (McCaughey, 2007; Beauchamp and Stein, 2008; Sinopoli and Lawless, 2012). Sodium chloride and mixtures of $\mathrm{NaCl}$ and $\mathrm{KCl}$ had the highest salty taste intensities. As the concentration was increased to $5 \times$ threshold for each salt, the salt solution with the highest salty taste was the $75: 25$ blend of $\mathrm{NaCl}: \mathrm{KCl}$. This was followed in salty taste intensity by $\mathrm{NaCl}, \mathrm{KCl}$, and 90:10 NaCl:KCl. At $5 \times$ threshold, $\mathrm{MgCl}_{2}$ and $\mathrm{CaCl}_{2}$ also had a bitter taste. The salt with the highest intensity for salty taste at $10 \times$ concentration was the $75: 25$ blend of $\mathrm{NaCl}: \mathrm{KCl}$, and this solution did not have detectable bitter taste. Other studies have reported that $\mathrm{NaCl}$ decreases the bitter taste detected in $\mathrm{KCl}$ when blended (Keast and Hayes, 2011).

\section{Sources of Salty Taste}

The compositional elements of permeate with significant correlation to salty taste intensity were $\mathrm{KCl}$, lactic acid, citric acid, orotic acid, hippuric acid, and NPN
$\left(\mathrm{R}^{2}=0.87,0.77,0.61,0.55,0.57\right.$, and 0.62 , respectively; $P<0.05)$. Elements with significant correlation values $(P<0.05)$ were evaluated in permeate models to determine their effect on salty taste.

\section{Taste Response Curves and Model Permeates}

Sodium chloride, both without added lactose and with lactose, had lower salty taste intensity scores $(P<$ $0.05)$ than whey permeate and reduced-lactose permeate (mean $=2.1$ and 10.5, respectively) at similar concentrations of $\mathrm{NaCl}$ (Figure 3). The addition of lactose decreased the salty taste intensity of $\mathrm{NaCl}$ solutions $(P$ $<0.05$ ). Sweet taste suppresses salty taste (Pangborn, 1959). Permeates elicited a higher salty taste response than the same concentration of $\mathrm{NaCl}$ alone, suggesting that other components of permeate contribute to salty taste. The reduced-lactose permeates had the highest salty taste intensity, which would be expected because minerals and organic acids were concentrated.

Potassium chloride, lactic acid, citric acid, orotic acid, hippuric acid, uric acid, and urea were selected for creation of permeate models because they had a significant correlation $(P<0.05)$ with salty taste. Uric acid and urea were selected as the primary sources of NPN. When $\mathrm{KCl}$ was added to $\mathrm{NaCl}$, the perceived salty taste intensity increased in the presence or absence of lactose $(P<0.05$; Figure 4$)$. Other research has reported that partial substitution of $\mathrm{KCl}$ with $\mathrm{NaCl}$ enhances salty taste and also reduces the bitterness of $\mathrm{KCl}$ alone (Keast and Hayes, 2011). Whey permeates had greater salty taste intensity than $\mathrm{NaCl}$ alone but when $\mathrm{KCl}$ was added to permeate models, the salty taste intensity of the models was the same as that for whey permeates $($ mean $=2.1$ salty taste intensity; $P$ $>0.05$; Figure 4). The second $\mathrm{KCl}$ curve included the highest concentration of $\mathrm{KCl}$ that was found in the reduced-lactose permeates. The increased concentration of $\mathrm{KCl}$ yielded a greater salty taste intensity than that of $\mathrm{NaCl}$ alone or of the lower concentration of $\mathrm{KCl}$ $(P<0.05$; Figure 5).

The addition of $0.01 \mathrm{M}$ lactic acid to $\mathrm{NaCl}$ also enhanced the perceived salty taste intensity compared with $\mathrm{NaCl}$ alone $(P<0.05$; Figure 6$)$. Lactic acid and $\mathrm{NaCl}$ with and without lactose had increased salty taste intensities similar to that found in whey permeates $($ mean $=2.1 ; P>0.05)$. Citric acid and $\mathrm{NaCl}$ were higher in salty taste intensity than $\mathrm{NaCl}$ alone $(P<$ $0.05)$ but with the addition of lactose, salty intensity was similar to that of $\mathrm{NaCl}(P>0.05)$. All permeate types had a higher salty taste intensity than citric acid and $\mathrm{NaCl}$ or $\mathrm{NaCl}$ alone $(P<0.05$; results not shown). Orotic acid increased salty taste intensities $(P<0.05$; Figure 7). Uric acid, hippuric acid, and urea did not 


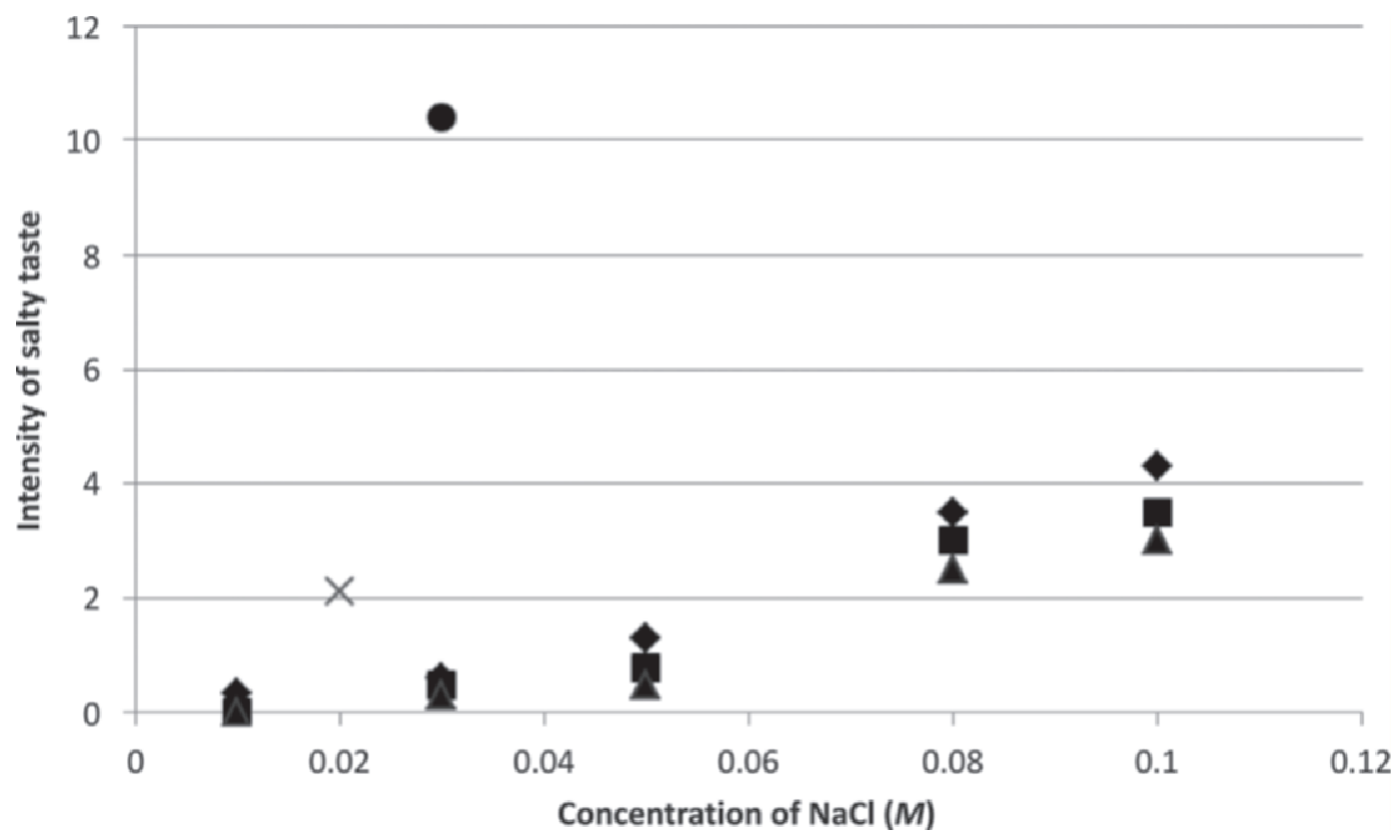

Figure 3. Salty taste response curves of permeate and NaCl-lactose solutions: $\mathrm{NaCl}$ and no lactose $(\bullet) ; \mathrm{NaCl}$ and $5 \%$ lactose $(\mathbf{\square}) ; \mathrm{NaCl}$ and $10 \%$ lactose $(\mathbf{\Lambda})$; mean of whey permeate $(\times)$; and mean of reduced-lactose permeate $(\mathbf{\bullet})$. A universal scale $(0$ to 15$)$ was used for intensities.

increase the salty taste of $\mathrm{NaCl}$ solutions $(P>0.05)$ nor were these compounds salty tasting (results not shown). Uric acid was sour and urea was bitter at the mean concentration detected in permeates. Hippuric acid in permeates was below the sensory threshold. The $\mathrm{pH}$ of all acids was taken to see if $\mathrm{pH}$ had an effect on salty taste enhancement. All acids at concentration in permeate had a similar $\mathrm{pH}$ range.

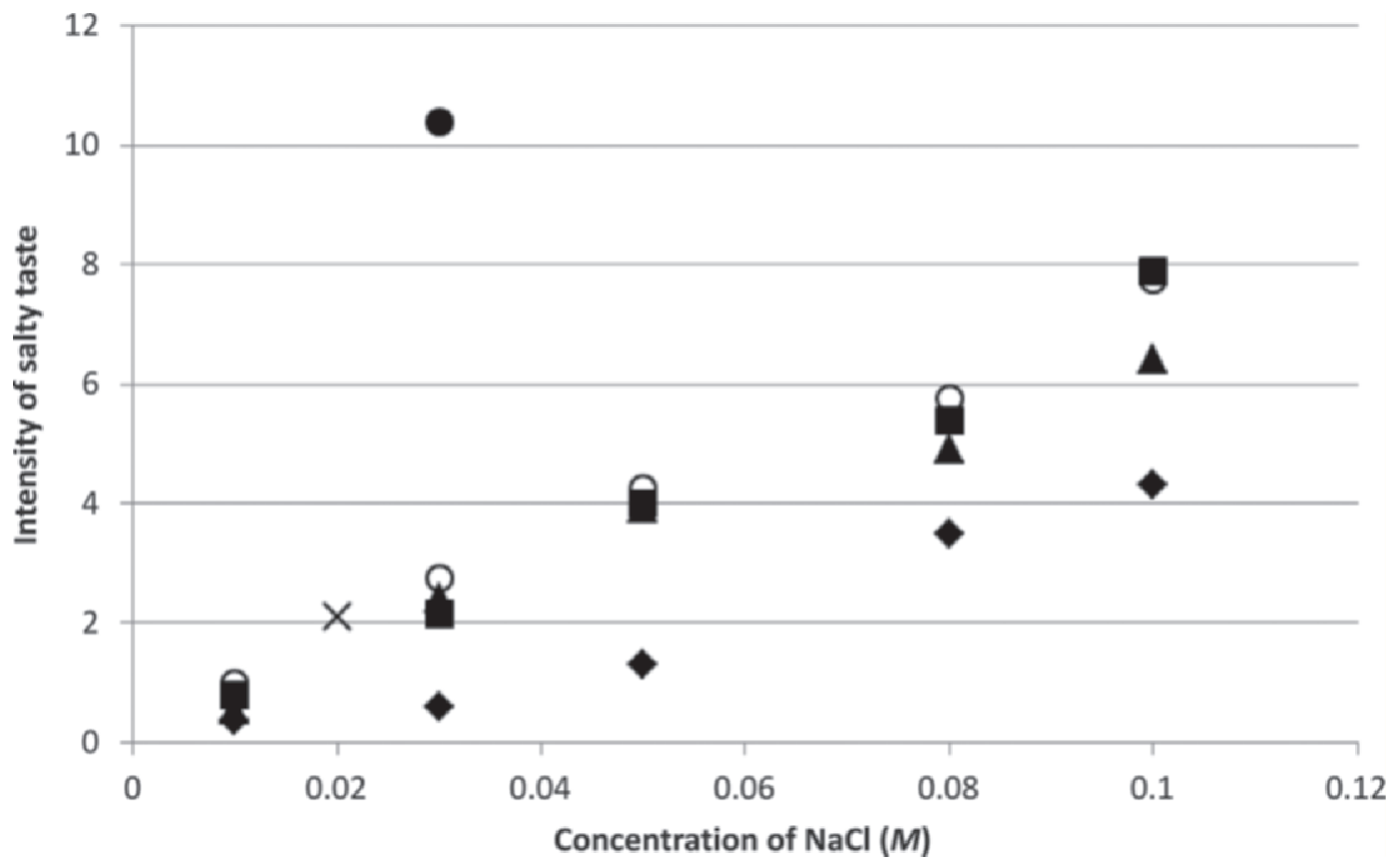

Figure 4. Salty taste response curves of $\mathrm{NaCl}$ and $0.05 \mathrm{M} \mathrm{KCl}$ with and without lactose: $\mathrm{NaCl}$ and no lactose $(\diamond) ; \mathrm{NaCl}+\mathrm{KCl}, \mathrm{no}$ lactose $(\bigcirc) ; \mathrm{NaCl}, \mathrm{KCl}$, and $5 \%$ lactose $(\mathbf{\square}) ; \mathrm{NaCl}, \mathrm{KCl}$, and $10 \%$ lactose $(\mathbf{\Lambda})$; mean of whey permeate $(\times)$; and mean of reduced-lactose permeate $(\bullet)$. A universal scale (0 to 15$)$ was used for intensities. 


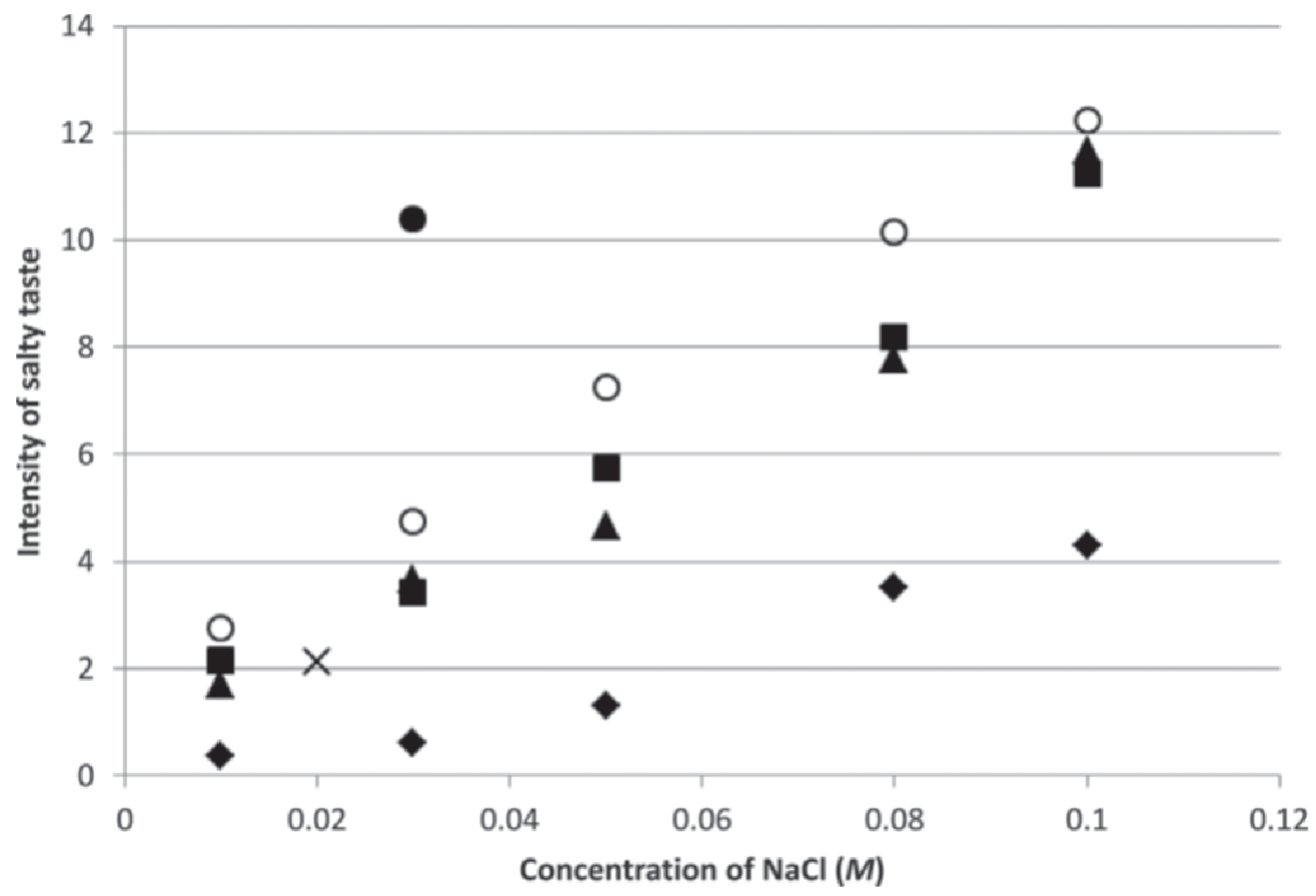

Figure 5. Salty taste response curve of $\mathrm{NaCl}$ and $0.10 \mathrm{M} \mathrm{KCl}$ with and without lactose: $\mathrm{NaCl}$ and no lactose $(\bullet) ; \mathrm{NaCl}+\mathrm{KCl}, \mathrm{no}$ lactose $(\bigcirc) ; \mathrm{NaCl}, \mathrm{KCl}$, and $5 \%$ lactose $(\mathbf{\square}) ; \mathrm{NaCl}, \mathrm{KCl}$, and $10 \%$ lactose $(\mathbf{\Delta})$; mean of whey permeate $(\times)$; and mean of reduced lactose permeate $(\bullet)$. A universal scale (0 to 15$)$ was used for intensities.

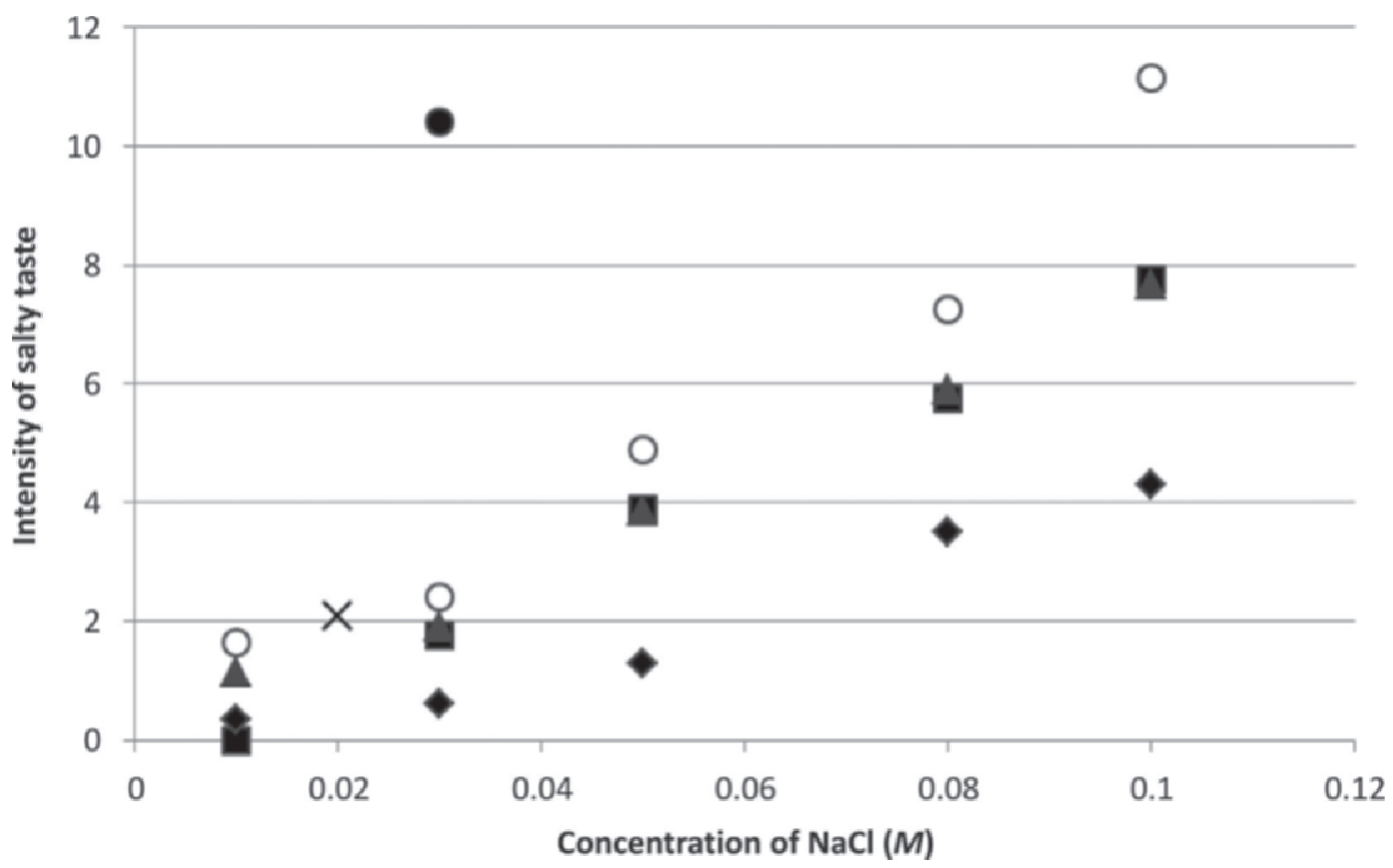

Figure 6. Salty taste response curves of $\mathrm{NaCl}$ and $0.01 M$ lactic acid with and without lactose. $\mathrm{NaCl}(\bullet) ; \mathrm{NaCl}+$ lactic acid, no lactose $(\bigcirc)$; $\mathrm{NaCl}$, lactic acid, and $5 \%$ lactose $(\mathbf{\square}) ; \mathrm{NaCl}$, lactic acid, and $10 \%$ lactose $(\mathbf{\Lambda})$; mean whey permeate $(\times)$; and mean of reduced lactose permeate (•). A universal scale (0 to 15$)$ was used for intensities. 


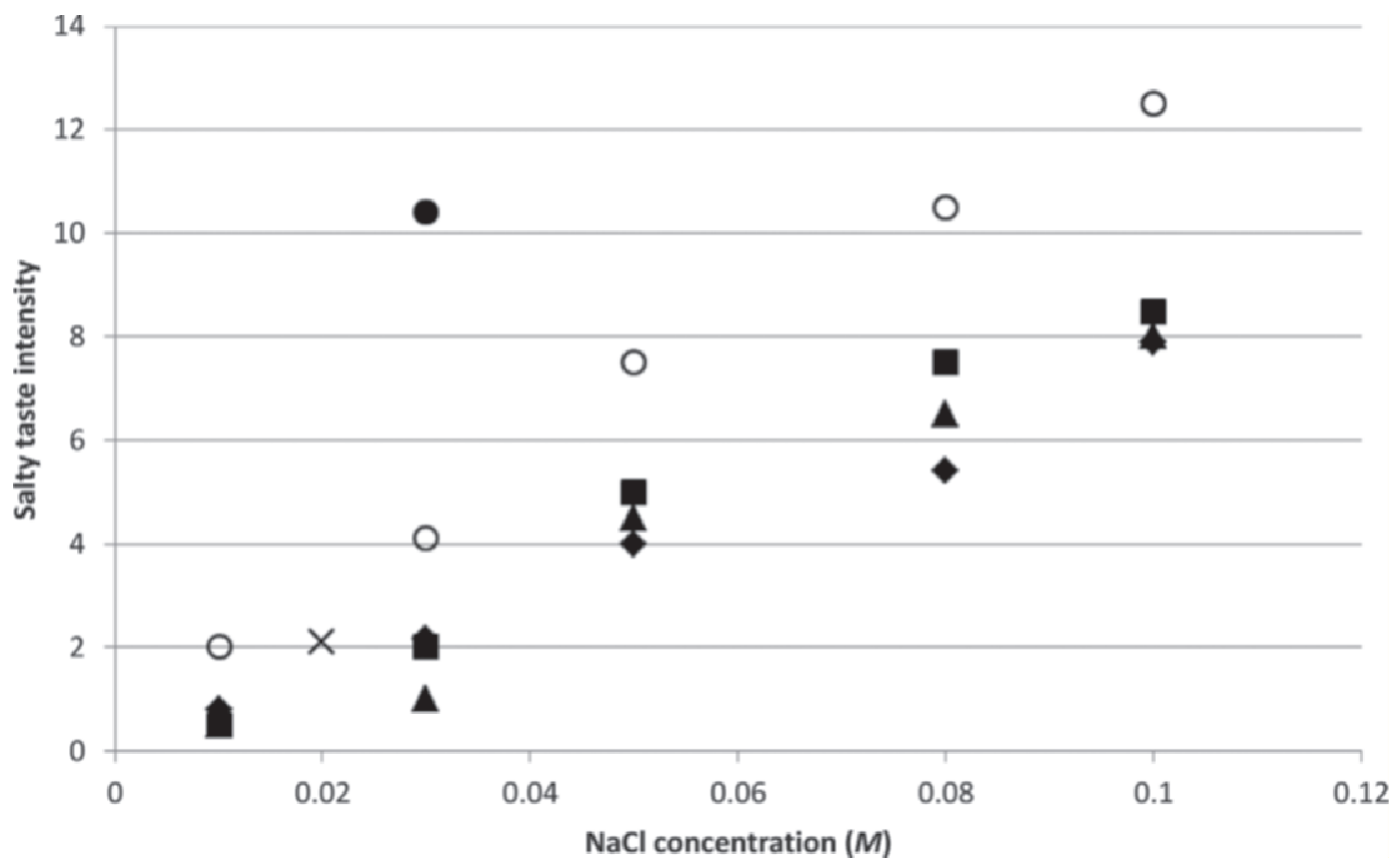

Figure 7. Salty taste response curves of $\mathrm{NaCl}$ and $3.84 \mathrm{~m} M$ orotic acid with and without lactose: $\mathrm{NaCl}(\bullet) ; \mathrm{NaCl}$ and orotic acid $(\bigcirc) ; \mathrm{NaCl}$, orotic acid, and $5 \%$ lactose $(\boldsymbol{\square}) ; \mathrm{NaCl}$, orotic acid, and $10 \%$ lactose $(\mathbf{\Delta})$; mean of whey permeate $(\times)$; and mean of reduced lactose permeate (-). A universal scale (0 to 15) was used for intensities.

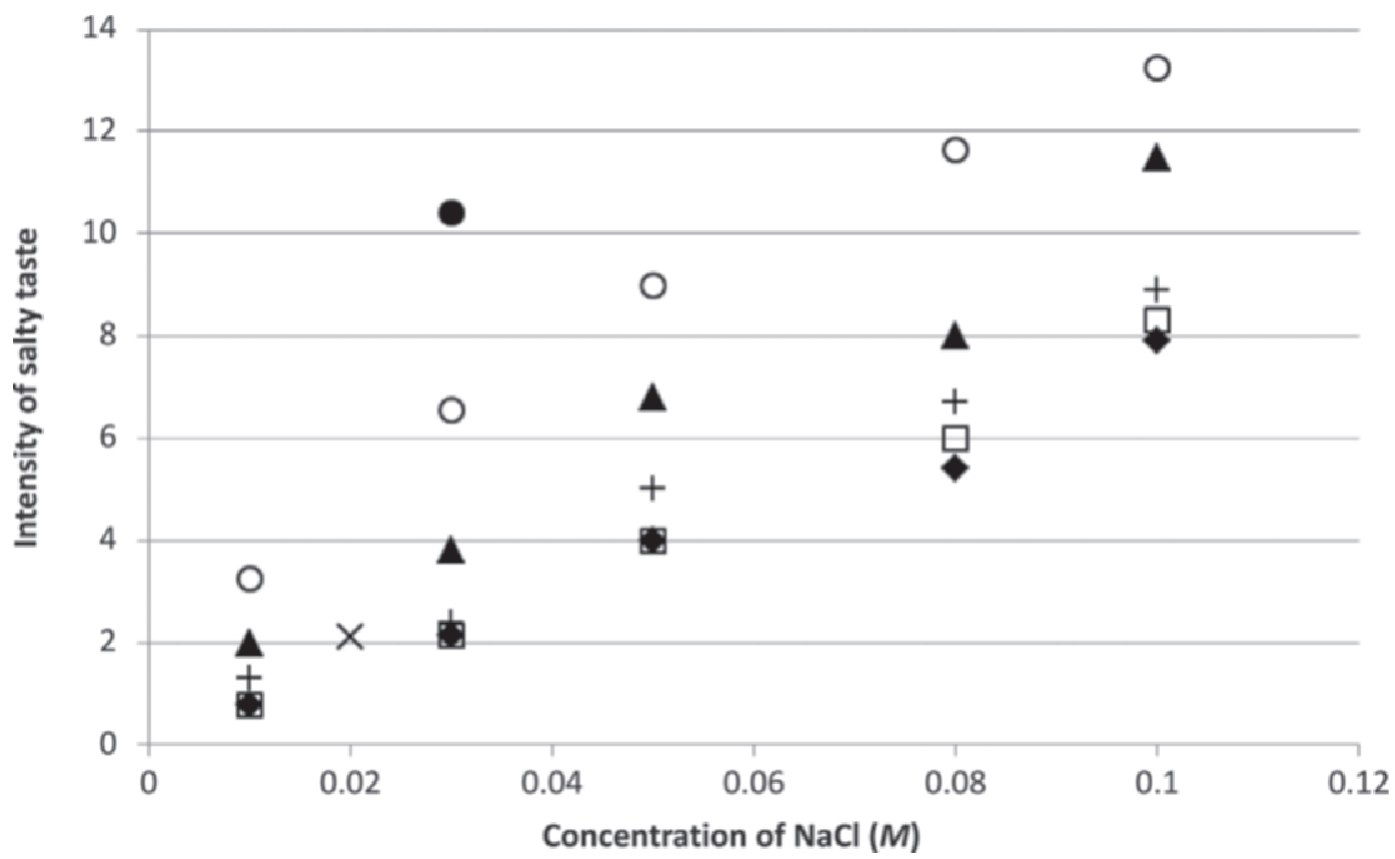

Figure 8. Salty taste intensities of $\mathrm{NaCl}, \mathrm{KCl}$, acid, and $5 \%$ lactose models: $\mathrm{NaCl}$ and $0.10 \mathrm{M} \mathrm{KCl}$ with $5 \%$ lactose ( $) ; \mathrm{NaCl}, 0.10 \mathrm{M} \mathrm{KCl}$, $0.01 M$ lactic acid with $5 \%$ lactose (O); NaCl, $0.10 M$ KCl, $3.84 \mathrm{~m} M$ orotic acid with $5 \%$ lactose $(\mathbf{\Lambda}) ; \mathrm{NaCl}, 0.10 M \mathrm{KCl}, 1.00 \mathrm{~m} M$ citric acid with $5 \%$ lactose $(+) ; \mathrm{NaCl}, 0.10 \mathrm{M} \mathrm{KCl}, 0.69 \mathrm{~m} M$ hippuric acid with $5 \%$ lactose $(\square)$; mean of whey permeate $(\times)$; and mean of reduced lactose permeate (-). A universal scale (0 to 15) was used for intensities. 


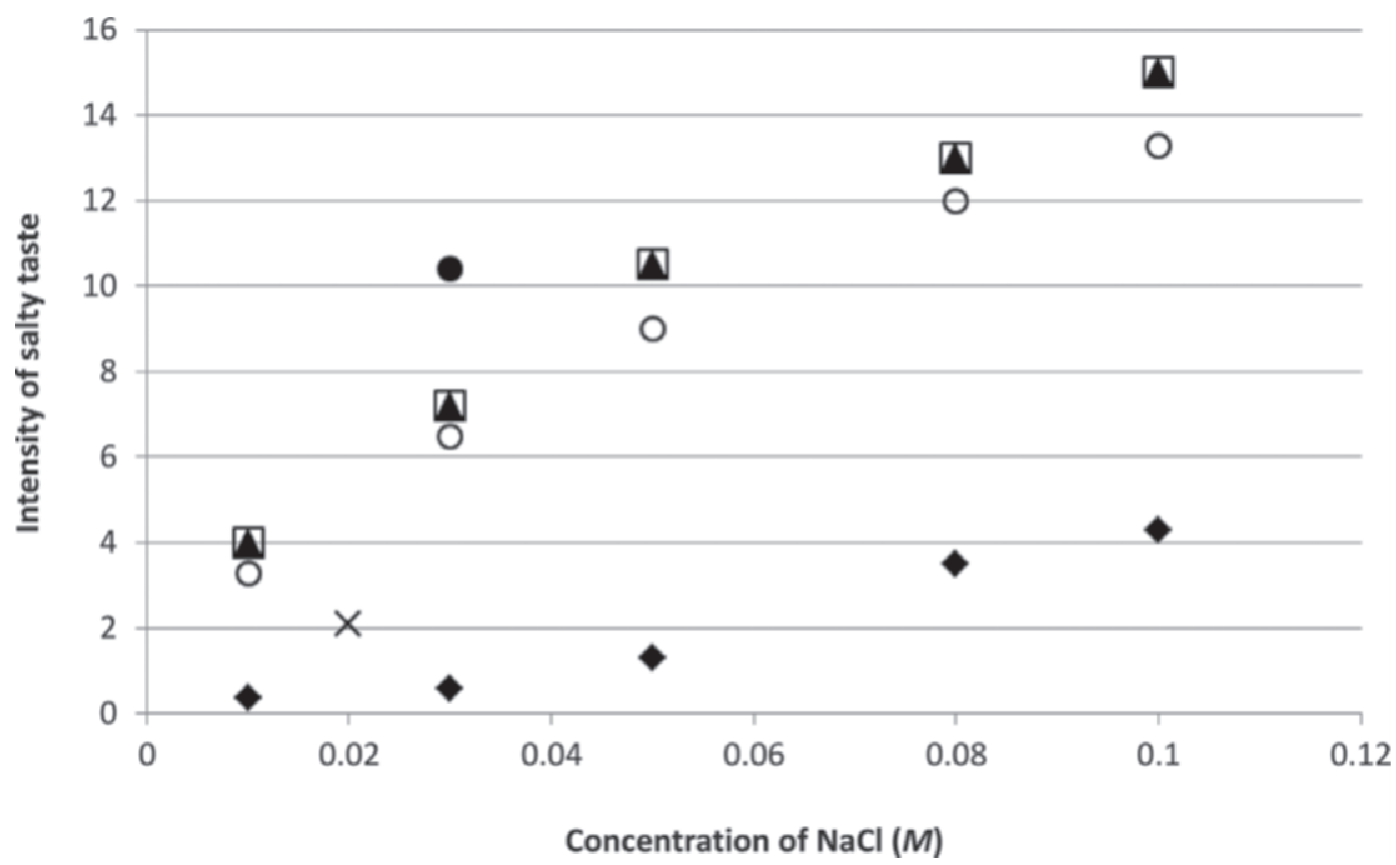

Figure 9. Salty taste response of different combinations of possible salty taste compounds: $\mathrm{NaCl}(\checkmark) ; 0.10 \mathrm{M} \mathrm{KCl}, 0.01 M$ lactic acid, and $5 \%$ lactose (○); $0.10 \mathrm{M} \mathrm{KCl}, 0.01 \mathrm{M}$ lactic acid, $5 \%$ lactose, and $3.84 \mathrm{~m} M$ orotic acid ( $\square$ ); $0.10 \mathrm{M} \mathrm{KCl,} 0.01 \mathrm{M}$ lactic acid, $5 \%$ lactose, $1.00 \mathrm{~m} M$ citric, $0.69 \mathrm{~m} M$ hippuric, $3.84 \mathrm{~m} M$ orotic, $1.78 \mathrm{~m} M$ uric acids, and $0.52 M$ urea $(\mathbf{\Lambda})$; mean of whey permeate $(\times)$; and mean of reduced lactose permeate (-). A universal scale (0 to 15$)$ was used for intensities.

Sodium chloride was combined with $\mathrm{KCl}$ and varying acids to determine if the addition of acid increased salty taste more than did $\mathrm{NaCl}$ or $\mathrm{KCl}$ (Figure 8). Citric or hippuric acid did not increase salty intensity more than $\mathrm{KCl}$ or $\mathrm{NaCl}$ alone $(P>0.05)$, whereas lactic or orotic acids did $(P<0.05$; Figure 8$)$. This result suggests that $\mathrm{KCl}$ is not the only factor increasing the salty taste in permeates. The addition of lactic or orotic acid to $\mathrm{KCl}$ and $\mathrm{NaCl}$ increased the salty taste intensity to that of whey permeates. Because reduced-lactose permeate is less than $5 \%$ lactose in solution it was still higher in salty taste intensity than the salty taste intensity of the model permeate.

Finally, 3 salty taste models were constructed (Figure 9). The first was $\mathrm{KCl}$, lactic acid, lactose, and $\mathrm{NaCl}$. The second included elements from the study that increased salty taste intensity of $\mathrm{NaCl}$ with lactose: this model included $\mathrm{KCl}$, lactic acid, lactose, and orotic acid. The third included all elements that were correlated with salty taste: $\mathrm{KCl}$, lactic acid, citric acid, hippuric acid, orotic acid, uric acid, and urea. All 3 models had increased salty taste intensity compared with $\mathrm{NaCl}$ with lactose $(P<0.05)$. Model 2 had higher salty taste intensity than model $1(P<0.05)$, suggesting that other elements besides $\mathrm{KCl}$ and lactic acid increase salty taste. Model 2 did not differ in salty taste from model $3(P>0.05)$. This suggests that orotic acid also increased salty taste intensity because it was absent in model 1 but the addition of other acids and urea did not further increase salty taste in model 3. To further investigate this possibility, $\mathrm{KCl}$, lactic acid, and orotic acid concentrations that were evaluated in the model were added to whey permeates with low salty taste intensities $($ mean $=1.8$ and 0.5 ). With addition of $0.1 M \mathrm{KCl}, 0.01 M$ lactic acid, and $3.84 \mathrm{~m} M$ orotic acid, salty taste intensities of the low-salty-taste whey permeates were increased ( 0.5 increased to 8 and 1.8 increased to $6.9 ; P<0.05)$.

\section{CONCLUSIONS}

Elements in whey permeate in addition to sodium provide salty taste. Lactic acid and $\mathrm{KCl}$ have the greatest salty-taste enhancement effect in permeate. Less sodium could be added to foods by using permeate as the salty taste source. Reduced-lactose permeate has the highest salty taste intensity and the highest concentration of these compounds and would best be suited as a replacement for sodium in food products. To maximize the potential of whey permeate as a salt replacer, the product should have higher concentrations of both lactic acid and $\mathrm{KCl}$. One potential way to increase lactic acid would be to start with acidified whey or with acid whey from cottage cheese or Greek yogurt. If lactic acid is at a higher concentration initially in fluid whey, more will be present in the permeate following membrane 
fractionation. Moreover, nanofiltration could be used to separate the minerals from the lactose.

\section{ACKNOWLEDGMENTS}

Funding was provided in part by the Dairy Research Institute (Rosemont, IL). The use of trade names does not imply endorsement nor lack of endorsement by those not mentioned.

\section{REFERENCES}

Anastasi, G., M. L. Antonelli, A. Biondi, and G. Vinci. 2000. Orotic acid: A milk constituent. Enzymatic determination by means of a new microcalorimetric method. Talanta 52:947-952.

Anderson, C. A., J. Lawrence, N. Okuda, I. Brown, Q. Chan, L. Zhao, H. Ueshima, H. Kesteloot, D. Curb, K. Yoshita, P. Elliott, M. Yamamoto, and J. Stamler. 2010. Dietary sources of sodium in China, Japan, the United Kingdom, and the United States, women and men aged 40 to 59 years: The INTERMAP Study. J. Am. Diet. Assoc. 110:736-745.

AOAC International. 2000. Official Methods of Analysis. 17th ed. AOAC International, Gaithersburg, MD.

Archwamety, R. 2012. Salt reduction, yogurt among ingredient application trends. Cheese Market News 32:16.

ASTM (American Society for Testing and Materials). 2003. Standard practice for determination of odor and taste thresholds by a forced-choice ascending concentration series method of limits. E679-91, Pages 42-46 in Annual Book of ASTM Standards. Vol. 15.08. ASTM Intl., West Conshohocken, PA.

Ballance, P. E. 1961. Production of volatile compounds related to the flavor of foods from Strecker degradation of DL-methionine. J. Sci. Food Agric. 12:532-536.

Ball, P., D. Woodward, A. Shoobridge, and M. Ferrier. 2002. Calcium diglutamate improves the taste characteristics of lower salt soup. Eur. J. Clin. Nutr. 56:519-523.

Beauchamp, G. K., and L. J. Stein. 2008. Salt taste. Pages 401-408 in The Senses: A Comprehensive Reference. 4. Elsevier, New York, NY.

Bendall, J. G. 2001. Aroma compounds of fresh milk from New Zealand cows fed different diets. J. Agric. Food Chem. 49:4825-4832.

Berg, J. M., J. L. Tymoczko, and L. Stryer. 2002. Section 24.4: Amino acids are precursors of many biomolecules. Biochemistry. 5th ed. W. H. Freeman, New York, NY.

Berry, D. 2010. Sodium reduction strategies. Dairy Foods 5:54-58.

Breslin, P. A., and G. Beauchamp. 1995. Suppression of bitterness by sodium: Variation among bitter taste stimuli. Chem. Senses 20:609-623.

Burdock, G. A. 2010. Page 188 in Fenaroli's Handbook of Flavor Ingredients. 6th ed. Taylor and Francis Group, Boca Raton, FL.

Cachon, R., and C. Divies. 1993. A descriptive model for citrate utilization by Lactococcus lactis ssp. lactis bv. diacetylactis. Biotechnol. Lett. 15:837-842.

Cachon, R., and C. Divies. 1994. Generalized model of the effect of $\mathrm{pH}$ on lactate fermentation and citrate bioconversion in Lactococcus lactis ssp. lactis biovar. diacetylactis. Appl. Microbiol. Biotechnol. 41:694-699.

Cadwallader, K. R., M. A. Drake, M. E. Carunchia Whetstine, and T. K. Singh. 2006. Characterisation of Cheddar cheese flavor by sensory directed instrumental analysis and model studies. Dev. Food Sci. 43:157-160.

Campbell, R. E., M. C. Adams, M. A. Drake, and D. M. Barbano. 2013. Effect of bleaching permeate from microfiltered skim milk on $80 \%$ serum protein concentrate. J. Dairy Sci. 96:1387-1400.

Carunchia Whetstine, M. E., A. E. Croissant, and M. A. Drake. 2005. Characterization of dried whey protein concentrate and isolate flavor. J. Dairy Sci. 88:3826-3839.
Carunchia Whetstine, M. E., J. D. Parker, M. A. Drake, and D. K. Larick. 2003. Determining flavor and flavor variability in commercially produced liquid cheddar whey. J. Dairy Sci. 86:439-448.

Contarini, G., and M. Povolo. 2002. Volatile fraction of milk: Comparison between purge and trap and solid phase microextraction techniques. J. Agric. Food Chem. 50:7350-7355.

Contarini, G., M. Povolo, R. Leardi, and P. M. Toppino. 1997. Influence of heat treatment on the volatile compounds of milk. J. Agric. Food Chem. 45:3171-3177.

Delwiche, J. 1996. Are there basic tastes? Trends Food Sci. Technol. $7: 411-415$.

Desai, N. T., L. Shepard, and M. A. Drake. 2013. Sensory properties and drivers of liking for Greek yogurts. J. Dairy Sci. 96:74547466 .

Drake, M. A., Y. Karagul-Yuceer, K. R. Cadwallader, G. V. Civille, and P. S. Tong. 2003. Determination of the sensory attributes of dried milk powders and dairy ingredients. J. Sens. Stud. 18:199216.

Drake, S. L., M. E. Carunchia Whetstine, M. A. Drake, P. Courtney, K. Fligner, J. Jenkins, and C. Pruitt. 2007. Sources of umami taste in Cheddar and Swiss cheese. J. Food Sci. 72:S360-S366.

Ferreira, I. M. P. L. V. O. 2003. Quantification of non-protein nitrogen components of infant formulae and follow-up milks: Comparison with cows' and human milk. Br. J. Nutr. 90:127-133.

Ferreira, I. M. P. L. V. O., E. Mendes, A. M. P. Gomes, M. A. Faria, and M. A. Ferriera. 2001. The determination and distribution of nucleotides in dairy products using HPLC and a diode array detector. Food Chem. 74:239-244.

Ferretti, A., and V. P. Flanagan. 1971. Volatile constituents of whey powder subjected to accelerated browning. J. Dairy Sci. 54:17641768 .

Ferretti, A., and V. P. Flanagan. 1972. Steam volatile constituents of stale nonfat dry milk. Role of the Maillard reaction in staling. J. Agric. Food Chem. 20:695-698.

Frankel, E. N. 1983. Volatile lipid oxidation products. Prog. Lipid Res. 22:1-33.

Gerdes, S. 2011. Food makers turn to whey permeate. Dairy Foods 112:42.

Giesecke, D., L. Ehrentreich, and M. Stangassinger. 1994. Mammary and renal excretion of purine metabolites in relation to energy intake and milk yield in dairy cows. J. Dairy Sci. 77:2376-2381.

Gillette, M. 1985. Flavor effects of sodium chloride. Food Technol. $39: 47-52 ., 56$

Girsh, L. S. 2001. Dairy permeate-based beverage. United States Patent Application 09/731,608 (abandoned).

Guu, M. Y. K., and R. R. Zall. 1991. Lactose crystallization: Effect of minerals and seeding. Process Biochem. 26:167-172.

Huber, J. T. 1975. Protein and non-protein nitrogen utilization in practical dairy rations. J. Anim. Sci. 41:954-961.

Islam, M. I. U., and T. A. G. Langrish. 2010. An investigation into lactose crystallization under high temperature conditions during spray drying. Food Res. Int. 43:46-56.

Kang, M. W., S. J. Chung, H. S. Lee, Y. Kim, and K. O. Kim. 2007. The sensory interactions of organic acids and various flavors in ramen soup systems. J. Food Sci. 72:S639-S647.

Karagul-Yuceer, Y., K. R. Cadwallader, and M. A. Drake. 2002. Volatile flavor components of stored nonfat dry milk. J. Agric. Food Chem. 50:305-312.

Keast, R. S. J., and J. E. Hayes. 2011. Successful sodium reduction. The world of food ingredients. September 2011:10-3. Accessed October 2011. http://www.foodingredientsfirst.com/magazine-digits/ Successful-Sodium-Reduction.html.

Kieronczyk, A., S. Skeie, T. Langsrud, and M. Yvon. 2003. Cooperation between Lactococcus lactis and nonstarter lactobacilli in the formation of cheese aroma from amino acids. Appl. Environ. Microbiol. 69:734-739.

Kim, M. K., K. Lopetcharat, P. D. Gerard, and M. A. Drake. 2012. Consumer awareness of salt and salt and sodium reduction and sodium labeling. J. Food Sci. 77:S307-S313. 
Labuza, T. P., and M. Saltmarch. 1981. Kinetics of browning and protein quality loss in whey powders during steady state and nonsteady state storage conditions. J. Food Sci. 47:92-96.

Lawless, H. T., O. C. Hartano, and S. Hernandez. 2000. Thresholds and suprathreshold intensity functions of capsaicin oil and aqueous based carriers. J. Sens. Stud. 15:437-447.

Lues, J. F. R., W. C. Botha, and E. J. Smit. 1998. Ion-exchange HPLC analysis of a broad spectrum of organic acids from matured cheddar cheese and the assessment of extraction methods. Food Res. Int. 31:441-447.

Mahajan, S. S., L. Goddik, and M. C. Qian. 2004. Aroma compounds in sweet whey powder. J. Dairy Sci. 87:4057-4063.

Marsili, R. T., H. Ostapenki, R. E. Simmons, and D. E. Green. 1981. High performance liquid chromatographic determination of organic acids in dairy products. J. Food Sci. 46:52-57.

Mattes, R. D., and D. Donnelly. 1991. Relative contributions of dietary sodium sources. J. Am. Coll. Nutr. 10:383-393.

McCaughey, S. 2007. Dietary salt and flavor: mechanisms of taste perception and physiological controls. Pages 77-98 in Reducing Salt in Foods: Practical Strategies. D. Kilcast and F. Angus, ed. Woodhead Publishing Cambridge, UK.

Moatsou, G., A. Hatzinaki, I. Kandarakis, and E. Anifantakis. 2003 Nitrogenous fractions during the manufacture of whey protein concentrates from feta cheese. Food Chem. 81:209-217.

Mullin, W. J., and D. B. Emmons. 1997. Determination of organic acids and sugars in cheese, milk, and whey by high performance liquid chromatography. Food Res. Int. 30:147-151.

Murphy, C., A. V. Cardello, and J. G. Brand. 1981. Tastes of fifteen halide salts following water and $\mathrm{NaCl}$ : Anion and cation effects. Physiol. Behav. 26:1083-1095.

NMI (National Marketing Institute). 2008. The 2008 Health and Wellness Trends Report. 9th ed. NMI, Harleysville, PA.

O'Brien, J. M., and P. A. Morrissey. 1989. The Maillard reaction in milk products. Heat induced changes in milk. Pages 53-61. Int. Dairy Fed, Brussels, Belgium.

Okiyama, A., and G. K. Beauchamp. 1998. Taste dimensions of monosodium glutamate (MSG) in a food system: Role of glutamate in young American subjects. Physiol. Behav. 65:177-181.

Oliveira, C., I. M. P. L. V. O. Ferreira, E. Mendes, and M. Ferreira. 1999. Development and application of an HPLC/diode array methodology for determination of nucleotides in infant formulae and follow-up milks. J. Liq. Chromatogr. Rel. Technol. 22:571-578.

Pangborn, R. M. 1959. Taste interrelationships. J. Food Sci. 29:245256 .

Robinson, J. L. 1980. Bovine milk orotic acid: Variability and significance for human nutrition. J. Dairy Sci. 63:865-871.

Roininen, K., M. L. Lahteenmaki, and H. Tuorila. 1996. Effect of umami taste on pleasantness of low-salt soups during repeated testing. Physiol. Behav. 60:953-958.

Salles, C., N. Sommerer, C. Septier, S. Issanchou, C. Chabanet, A. Garem, and J. L. Le Quere. 2002. Goat cheese flavor: Sensory evaluation of branched fatty-chain fatty acids and small peptides. J. Food Sci. 67:835-841.

Schiffman, S. S., K. Sennewald, and J. Gagnon. 1981. Comparison of taste qualities and thresholds of D- and L-amino acids. Physiol. Behav. 27:51-59.
Shahani, K. M., and H. H. Sommer. 1951. The protein and nonprotein nitrogen fractions in milk. I. Methods of analysis. J. Dairy Sci. 34:1003-1009.

Shepard, L., R. E. Miracle, P. Leksrisompong, and M. A. Drake. 2013. Relating sensory and chemical properties of sour cream to consumer acceptance. J. Dairy Sci. 96:5435-5454.

Shiratsuchi, H., M. Shimoda, K. Imayoshi, K. Noda, and Y. Osajima. 1994. Off-flavor compounds in spray dried skim milk powder. J. Agric. Food Chem. 42:1323-1327.

Sinopoli, D. A., and H. T. Lawless. 2012. Taste properties of potassium chloride alone and in mixtures with sodium chloride using a checkall-that-apply method. J. Food Sci. 77:S319-S322.

Tressel, R., B. Helak, N. Martin, and E. Kersten. 1989. Formation of amino acid-specific Maillard products and their contribution to thermally generated aromas. Pages $156-171$ in Thermal Generation of Aromas. American Chemical Society, Washington, DC.

US Dairy Export Council. 2011. Whey products definition, composition, and function. Reference Manual for U.S. Whey and Lactose Products. US Dairy Export Council, Arlington, VA.

US Department of Health and Human Services. 2006. Your guide to lowering your blood pressure: DASH eating plan. NIH publication No. 06-4082. Accessed Jun. 12, 2014. http://www.nhlbi.nih.gov/ health/public/heart/hbp/dash/new_dash.pdf.

US FDA (Food and Drug Administration). 2008. A food labeling guide. FDA Center for Food Safety and Applied Nutrition. Accessed Oct. 2011. http://www.fda.gov/Food/GuidanceRegulation/ GuidanceDocumentsRegulatoryInformation/LabelingNutrition/ ucm2006828.htm

USDA. 2010. Dietary Guidelines for Americans 2010 - Chapter 8: Sodium and potassium. US Department of Health and Human Services/US Department of Agriculture, Washington, DC. Accessed Oct. 2011. http://www.health.gov/dietaryguidelines/2010.asp.

Van Gemert, L. J. Compilations of odour threshold values in air, water and other media. 2003. Oliemans Punter \& Partners BV, the Netherlands.

Vazquez-Landaverde, P. A., G. Velazquez, J. A. Torres, and M. C Qian. 2005. Quantitative determination of thermally derived offflavor compounds in milk using solid-phase microextraction and gas chromatography. J. Dairy Sci. 88:3764-3772.

Whitson, M. E., R. E. Miracle, E. Bastian, and M. A. Drake. 2011. Effect of liquid retentate storage on flavor of spray-dried whey protein concentrate and isolate. J. Dairy Sci. 94:3747-3760.

Whitson, M. E., R. E. Miracle, and M. A. Drake. 2010. Sensory characterization of chemical components responsible for cardboard flavor in whey protein. J. Sens. Stud. 25:616-636.

Wright, B. J., S. E. Zevchak, J. M. Wright, and M. A. Drake. 2009 The impact of agglomeration and storage flavor and flavor stability of whey protein concentrate $80 \%$ and whey protein isolate. J. Food Sci. 74:S17-S29.

Yamaguchi, S., and C. Takahashi. 1984. Interaction of monosodium glutamate and sodium chloride on saltiness and palatability of clear soup. J. Food Sci. 49:82-85. 